\title{
Congressional agendas
}

\section{A US Congress newly dominated by Democrats needs to exercise financial restraint. Manned spaceflight is a good candidate for cuts, and energy research needs belated leadership.}

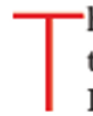
he Democrats who will make up majorities in both houses of the 110th US Congress in January face a difficult two years. Despite having their hands once again on the purse strings, without control of the executive there will be many areas where their ability to make good on the change they have promised will be constrained. But there is good that can be done on various issues of particular interest to the research community.

One tempting possibility is to use Congress's investigative powers to delve into the Bush administration's past and future use, and alleged abuse, of scientific advice. That may be useful in setting standards for future administrations of either party, and might well have practical political benefits. But it is not, for now, the highest priority.

That honour goes to policy on energy and climate. Congress will doubtless be keen to assert US leadership in this area; climate is, among other things, a particular interest of Senator Joe Biden, the likely chair of the Senate Committee on Foreign Relations. And the world would undoubtedly benefit from wise leadership over the next two years as the post-Kyoto agenda becomes clear. But anyleadership worthy of the name must be by example.

There are various proposals for cap and trade approaches to greenhouse gases that Democratic majorities might introduce to Congress - notably a bill sponsored by senators John McCain (Republican, Arizona) and Joe Lieberman (Democrat, Connecticut). Unfortunately, with the likelihood of vigorous opposition from the oil and gas lobby and the current administration's firm position on the other side of the argument, passing such legislation, while desirable, might not be possible. If that proves to be the case, it will be time to abandon the aggrandizing rhetoric of leadership, and to settle for signalling a statesmanlike interest in 'followership.' Finding ways to demonstrate that the United States is coming into line with informed opinion and policy in the rest of the world would in itself be a step forward.

Meanwhile, a strengthened commitment to energy research and development, and an honest approach to the evidence base in this area, should be more achievable. Congress should not turn its back on the possibility of renewed investment in nuclear power, as some Democrats will be keen to do. But it should also set up a proactive congressional review of which other energy technologies are ripe for development and innovation. Energy independence is a popular theme in the United States; solutions to the problem that also reduce carbon emissions have a clear mandate.

The new congressional leaders will find themselves in a more difficult position on the scientific issue that had the highest profile in the campaign: stem-cell research. The stance that led to President George W. Bush's regrettable veto of legislation that would have relaxed constraints on the use of federal funds for stem cells was not shared by all of his party - but not all Democrats favour overturning the veto. There is thus more reason than ever for the research community to furnish members of Congress with opportunities to educate themselves on the issues - an effort that, although it may take time, could prove vital to progress. What's more, if Bush's veto was an attempt to establish stem-cell research as a wedge issue that would help at the polls, it failed fairly comprehensively, so that opposition might conceivably be open to negotiation.

What the Democrats should not be expected to do is provide significant increases in funding overall - something they have both the power and the temptation to do. The damage done to America and the rest of the world by unsustainable deficits is real, and any lack of zeal in facing this problem would be a mistake. In that context, this would be a good time for Congress to look again at Bush's plans for NASA to re-establish a human presence in deep space. The outgoing Republican Congress gave its Republican president too much benefit of the doubt on this undertaking. The new Congress must, at the very least, articulate more convincing reasons than have yet been heard for such a colossal expenditure.

\section{Order for microbes}

\section{Burgeoning microbial gene data require coherent efforts to make them readily usable.}

M icrobes don't subscribe to the single life. They are coupled with complex ecosystems of diverse, mutually dependent species. This complexity and the vast numbers of microbes in the ocean, the soil, in our gut and almost everywhere else pose a challenge to those seeking to understand microbial ecology.

In the 1980 s, surveying the microbial world by sequencing the collective ribosomal RNA opened up new avenues. For the first time it was possible to get a glimpse of the make-up of complex microbial systems. It's a reasonable assumption that the more similar these sequences are, the more closely related the microbes are, and the more closely related their lifestyles must be - hence the pursuit of insights into what microbes might be doing in their environments.

But this assumption turned out to be fragile, as it emerged that microbes frequently shuffle around their genes both within and between species. A similarity in one gene does not necessarily correlate with the absence or presence of other genes in the genome.

Fortunately, the continuous decrease in sequencing costs allows today's microbiologists to sequence not only a single gene from each of the most abundant species in a microbial ecosystem, but also, at least in theory, all the genes present. These composite genomes, or 'metagenomes', provide a wealth of information that could only be dreamt of even a couple of years ago. With sequencing facilities 
continuing to increase their capacities by applying new technologies, and funding agencies supplying the necessary resources, sequencing the ocean or the contents of the human gut has become relatively easy. But how to extract meaningful information from a metagenome, and to gain insight into both the individual species' impact on the microbial community and the impact of this community on the ecosystem?

We can hope to unravel the function of every gene when individual species can be cultivated and genetically manipulated in the laboratory, but this is impossible when dealing with a complex community containing hundreds or thousands of species. Functional assignment of genes needs to be performed, even when the only information available is a string of nucleotide bases.

There are numerous databases and websites, public and not-sopublic, some adhering to an easily understandable framework of standards and regulation, and some not so transparent. Five years ago it was a big disappointment to compare one's chosen sequence with the GenBank database and not find a hit'. Today there is a feeling of sheer inadequacy in the face of vast quantities of sequence and annotation information - and an acute need for a degree in bioinformatics.

Publication in most cases (including the Nature journals) requires the deposition of sequence data into the GenBank or EMBL databases. Much less effort is spent depositing unpublished data or updating information that is already published. In all probability, in the not too distant future, metagenomic studies will be done not only by the big sequencing centres, but by anybody with a reasonable research budget and university support. To make all the data more easily accessible, it would be desirable to have a collaborative effort of genome centres and funding agencies to build a universal microbialsequence database, with a readily comprehensible framework for sequencing and annotation standards and regulations.

Microbiology has come a long way from investigating the easily cultured individual microbe from a rich microbial community and describing what is out there, and is now starting to get a grip on what they actually do. With the intrinsic difficulties of dealing with complex systems, it is good to see a field galvanized by new technologies and scientific daring. But more infrastructural order is required, to prevent the discipline getting ahead of itself.

\section{Success and successor}

\section{Exit an outstanding science minister; enter a more political operator.}

E arning the respect of the sector you represent isn't always a priority for a government minister, and can even lead your prime minister to suspect that you've 'gone native'. But when Tony Blair (to his credit) appointed David Sainsbury to be Britain's minister for science in 1998, he will have known that Sainsbury was native already, having a deep respect for science and having given it many millions of pounds of his personal philanthropy. Precisely because of his commitment to science, Sainsbury wanted that job and no other in government. That simple fact, combined with Sainsbury's quiet yet successfully determined support for science throughout his eight years, underlies the chorus of almost unmitigated praise from leading UK scientists following his resignation last week.

The disappointing aspects of this era mostly happened despite Sainsbury, rather than because of him. The 'spin' in government statistics - whether in budgetary announcements or in statistics of growth in undergraduate numbers - is a part of Blair's legacy for which his probable successor as prime minister, chancellor of the exchequer Gordon Brown, shares responsibility and would do well to discourage. As a government minister, Sainsbury cannot be wholly absolved from responsibility for something he nevertheless tried to resist: the relentless growth of academic bureaucracy, supposedly in aid of accountability. It no doubt runs counter not only to his sense of what researchers should be focusing on, but also to his experience, based in his family's supermarket empire, of how to run a business.

Sainsbury's strengths have included making the time to engage with scientists and to understand their goals. He has been influential internationally in his support for a politically untrammelled Euro- pean Research Council, and nationally in the way he has opposed and undermined vicious animal-rights activists. His time has been marred by accusations of conflicted interests, not least through hefty donations to a Labour party currently under police investigation for its handling of such support. But few believe that his reputation for integrity will be undermined when the results of that investigation are made public.

Sainsbury was luckier than most of his predecessors in that both his prime minister and his chancellor have been vigorous champions of science. But Sainsbury has had to defend his corner all the same. Now, the Treasury is focusing on critically analysing the benefits emerging from an unprecedented ten-year programme of annual increases in science funding.

Just what those increases amount to, given the exaggerations of spin and the pressures from commitments such as Iraq, education and public health, and just what benefits are demanded by the Treasury, are key issues for future scrutiny. Negotiating such challenges will be the responsibility of Sainsbury's successor, Malcolm Wicks - a member of parliament rather than a life peer and, by both definition and character, more of a political operator. Encouragingly, Wicks, in his current ministerial responsibilities for energy (which he will leave behind), has shown himself to be a good listener, prepared to consider evidence, and prepared to engage with lobbyists - yet also to face them down in public.

The respect and experience that Sainsbury has gained will stand him in good stead as he tackles his next commitment for the government: developing a strategic review of UK science policy. In this role, and in his position in the House of Lords, where he can scrutinize government legislation, and as a philanthropist, he can still influence science, and has earned the right to do so. 